\title{
The Complex Link between Apoptosis and Autophagy: a Promising New Role for RB
}

\author{
JOÃO M.A. DELOU, DEBORAH BIASOLI and HELENA L. BORGES \\ Instituto de Ciências Biomédicas, Universidade Federal do Rio de Janeiro, Av. Carlos \\ Chagas Filho, 373, Ilha do Fundão, 21949-590 Rio de Janeiro, RJ, Brazil \\ Manuscript received on March 14, 2016; accepted for publication on June 27, 2016
}

\begin{abstract}
Physiological processes, as autophagy, proliferation and apoptosis are affected during carcinogenesis. Restoring cellular sensitivity to apoptotic stimuli, such as the antineoplastic cocktails, has been explored as a strategy to eliminate cancer cells. Autophagy, a physiological process of recycling organelles and macromolecules can be deviated from homeostasis to support cancer cells survival, proliferation, escape from apoptosis, and therapy resistance. The relationship between autophagy and apoptosis is complex and many stimuli can induce both processes. Most chemotherapeutic agents induce autophagy and it is not clear whether and how this chemotherapy-induced autophagy might contribute to resistance to apoptosis. Here, we review current strategies to sensitize cancer cells by interfering with autophagy. Moreover, we discuss a new link between autophagy and apoptosis: the tumor suppressor retinoblastoma protein (RB). Inactivation of $\mathrm{RB}$ is one of the earliest and more frequent hallmarks of cancer transformation, known to control cell cycle progression and apoptosis. Therefore, understanding RB functions in controlling cell fate is essential for an effective translation of RB status in cancer samples to the clinical outcome.
\end{abstract}

Key words: retinoblastoma, neoplasm, autophagy, cell death, antineoplastic agents.

\section{INTRODUCTION}

Cells have evolved to sense and integrate signals from the environment in order to respond to it. In the presence of an environmental stimulus, which can be nutrients or a stress, intracellular pathways are activated, and their interaction determines how the cell will respond to such stimulus.

In the tumorigenic process, alterations in those pathways result in an imbalanced cell growth, originated from a misbalance between cell division and cell death. The traditional treatment for cancer is based on surgery and the exposure of cancer cells

Correspondence to: Helena L. Borges

E-mail: hborges@icb.ufrj.br to mainly two kinds of cytotoxic effectors: ionizing radiation (radiotherapy) and/or chemotherapeutical drugs (chemotherapy), which ultimately leads to the generation of DNA damage in an attempt to kill cancer cells. However, very frequently, not all of the cancer cells die, which results in the selection of the cells that can resist the therapy. It is, therefore, very important to understand how cancer cells respond to such therapy agents, and how cells integrate pathways that are activated in response to therapy that will lead to cell death or survival.

This review aims to discuss mostly two mechanisms that are very frequently activated by therapeutic agents, apoptosis and autophagy. Here, we focus on an emerging important pathway 
regarding the integration of those two mechanisms, the retinoblastoma protein $(\mathrm{RB})$ pathway.

\section{APOPTOSIS AND CANCER}

Apoptosis is a physiological process of metazoans involving a series of biochemical events in a specialized signal transduction pathway that ultimately leads to a regulated form of cell death in which dead cells do not release toxic components to its environment (Galluzzi et al. 2015a, Hacker 2013). The classical apoptotic process involves a cleavage cascade performed by cysteine proteases, called caspases (Thornberry and Lazebnik 1998). Activated caspases cleave cellular substrates (Boatright et al. 2003) to induce DNA fragmentation, nuclear condensation, cytoplasmic shrinkage, membrane blebbing and, thereafter, cell death and dissolution with the formation of apoptotic bodies (Figure 1) (Galluzzi et al. 2015b, Saraste and Pulkki 2000).

Apoptosis in cancer has been largely studied and it is well recognized that the apoptotic signaling pathway is obligatorily impaired or perverted during the oncogenic transformation process (Hanahan and Weinberg 2011). It is not surprising that reduced caspase activity is very commonly found in cancer cells (Shen et al. 2010, Devarajan et al. 2002) as well as the imbalance between the

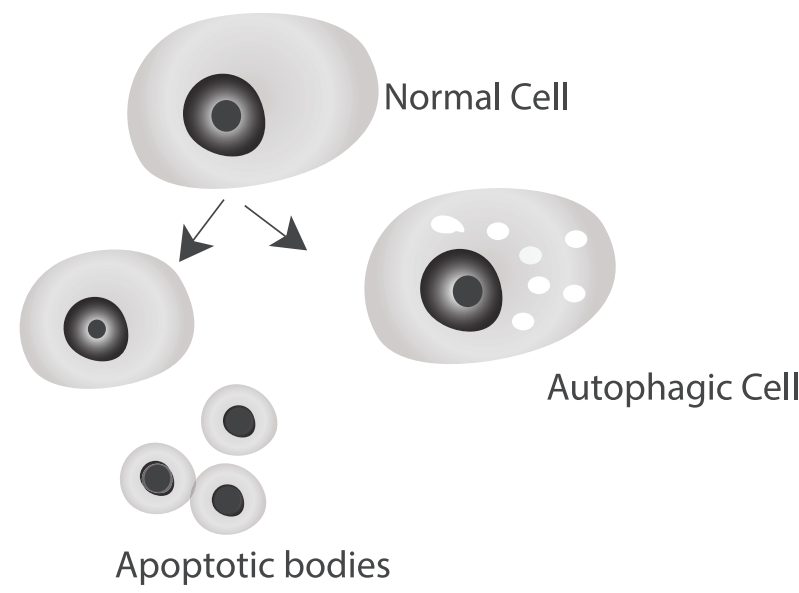

Figure 1 - Schematic view of the cell death by apoptosis with the cell size shrinking and fragmentation to form apoptotic bodies and autophagic cell with vacuoles. anti- and pro-apoptotic proteins BCL2 and BAX, respectively; which are important in the outcome regarding drug response (Pepper et al. 1997).

Alterations in the tumor suppressor p53 response are also very common in cancer. Humans with germline mutations on the TP53 gene develop a tumor predisposition syndrome called Li-Fraumeni (Malkin 2011), and 50\% of human tumor types present a mutated form of $\mathrm{p} 53$, which is often associated with poor prognosis and resistance to therapy (Kirsch and Kastan 1998). Additionally, it was shown that in melanoma cells, some downstream genes in the p53 pathway are deregulated, which leads to apoptosis evasion (Avery-Kiejda et al. 2011).

Restoring apoptosis is a therapeutic strategy to cancer treatment that has been explored and intensively studied. For example, oblimersen, an antisense oblimer to the BCL2 anti-apoptotic protein, was the first drug targeting BCL2 to go on clinical trial. The combination of oblimersen with conventional treatment resulted in chemosensitization (Knox et al. 2008). A phase III randomized trial of fludarabine and cyclophosphamide with or without oblimersen in 241 patients with relapsed/refractory CLL showed some benefit to patients. After 5 years, however, the benefits did not translate into a significant survival advantage for the oblimersen group (O'Brien et al. 2007, 2009). In summary, the development of small molecule inhibitors specific for antiapoptotic BCL2 proteins has been evaluated to potentiate efficacies of established drugs and might decrease the patient drug load by diminishing the required chemo-/radiotherapy dose, but more studies are necessary (Vogler 2014).

Small mimetics of BCL2-homology-3 (BH3)only proteins have being tested for cancer therapy in preclinical stage and also in clinical trials. ABT737 has been proved efficacious in killing certain leukemias, lymphomas, small cell lung cancer and multiple myelomas, as a single agent, in a BAX/ BAK dependent manner (Oltersdorf et al. 2005). 
Its orally derivative form ABT-263 was evaluated in clinical trials and in combination with another treatment, rituximab, was well tolerated as initial therapy for patients with CLL, yielded higher response rates than rituximab alone and resulted in prolonged progression-free survival with treatment beyond 12 weeks (Kipps et al. 2015).

Some small molecules that inhibit p53 and its inhibitor MDM2 interaction, and therefore stabilize and activate p53 have been developed. Nutlins are cis-imidazole analogues that have been shown to selectively induce senescence in cancer cells (Shangary and Wang 2009). MI-219, another inhibitor of p53-MDM2 interaction, selectively induces apoptosis in cancer cells and significantly reduces tumor growth (Shangary et al. 2008). Another strategy is to reactivate mutant p53 with small molecules like Prima-1, a compound that covalently binds to the mutated p53 protein and recovers its physiological function, reactivating its ability to activate apoptosis, leading to tumor cells death (Lambert et al. 2009). It is noteworthy that several publications have described a noncell autonomous tumor suppressor function for p53, for example by modulating factors secreted by liver stellate cells, culminating with a change in macrophages response and the inhibition of liver cancer associated with cirrhosis development (Lujambio et al. 2013). Moreover, p53 was shown to modulate astrocytes to secrete extracellular matrix that interfered with glioblastoma cells survival and migration (Lujambio et al. 2013, Biasoli et al. 2014). It will be, therefore, important to evaluate the effects of p53 modulating drugs in the tumor microenvironment in future studies.

\section{AUTOPHAGY}

Autophagy is a physiological process of organelles and macromolecules turnover and nutrients recycling, conserved in all eukaryotic organisms, from yeast to humans (Klionsky et al. 2011). During the multistep macroautophagic process, thereafter referred to as autophagy, the cytoplasmic content is caught by a structure called isolation membrane, which elongates and forms a double membrane vesicle called the autophagosome. The autophagosome then fuses with the lysosome, giving rise to the autolysosome, where the lysosomal enzymes finally degrade the cytoplasmic content (Klionsky 2005). Recent evidences have shown that the endoplasmic reticulum, Golgi and the mitochondria provide source for the isolation membrane formation (Tooze and Yoshimori 2010, Ge et al. 2014). Autophagy occurs in basal levels, but some stimuli result in massive induction (Figure 1).

\section{MOLECULAR REGULATION OF AUTOPHAGY}

Autophagy is physiologically regulated in multiple and redundant steps, since its initial events, associated to the formation of the isolation membrane, all along to its most terminal events, as the regulation of the activity of the autolysosome enzymes. Some of these events and modulators are highlighted here. ATGs (autophagy related proteins) were described in yeast and are conserved in eukaryotic organisms (Klionsky et al. 2003). When autophagy is induced, ATGs interact in complexes, culminating with the formation of the isolation membrane. In a complex cascade of conjugations, ATG12 binds to ATG5. This ATG12-ATG5 complex then binds to ATG16 that is important for the elongation of the isolation membrane. This phenomenon also depends on Vps34 activity, a PI3K class III, which explains why 3-methyladenine (3-MA, a PI3K inhibitor) prevents autophagosome formation (Tassa et al. 2003).

Also during autophagy process, microtubuleassociated protein 1A/1B-light chain 3 (LC3) is lipidated through conjugation with phosphatidylethanolamine (PE), generating the LC3-II form, which is then allocated in the autophagosome membrane (Yorimitsu and Klionsky 2005). The appearance of the LC3-II form has been one of the most used 
methods to detect the induction of autophagy. Notably, LC3 interacts with the p62 protein, which is often found inside autophagosomes, and is degraded when the autolysosome is formed. The decrease in p62 levels has been used for detecting an ongoing autophagic flux (Bjorkoy et al. 2005). Once the autophagosome is formed, it goes through maturation steps and then it fuses with the lysosome, being called autolysosome. The degradation of its content requires a low $\mathrm{pH}$ and proteinase $\mathrm{B}$, a hydrolase involved in the activation of many other vacuolar zymogens (Nakamura et al. 1997, Teter et al. 2001).

The mammalian target of rapamycin (mTOR) is central to the control of autophagy induction through many different pathways. mTOR is a serine/threonine kinase that plays key roles in the cellular responses to changes in nutrient conditions and energy metabolism. It inhibits autophagy by modulating signal transduction cascades to control transcription and translation, and it can directly control the activity of ATG. For example, mTOR causes hyperphosphorylation of ATG13, which prevents its binding to ATG1, therefore collaborating for the autophagy inhibition (Kamada et al. 2000).

Beclin-1 is the first described autophagyrelated tumor suppressor, which is consistently monoallelically deleted in $40-70 \%$ of all sporadic breast, ovarian and prostate cancers. When autophagy is induced, Beclin-1 is important for the Vps34 isolation membrane elongation activity (Liang et al. 1999). Beclin-1 is phosphorylated by ULK1, a serine/threonine kinase, in response to amino acid starvation, a fact that was shown to increase its activity on Vps34 (Russell et al. 2013). The interaction between Beclin-1 and AMBRA-1 (activating molecule in Beclin-1-regulated autophagy) has also been shown to increase its activity on Vps34 (Yazdankhah et al. 2014).

AMP activated protein kinase (AMPK) is activated in response to a variety of stimuli, such as nutrient deprivation, hypoxia and chemo/ radiotherapy. The active AMPK then inhibits mTOR activity and phosphorylates ULK1, thereby, inducing autophagy (Kim et al. 2011).

In normal conditions, the PI3K/AKT pathway activates mTOR, which down-regulates autophagy. In the presence of starvation conditions, the tumor suppressor phosphatase and tensin homolog, PTEN, dephosphorylates class I PI3-kinase, inhibiting the PI3K/AKT pathway, leading to autophagy activation through mTOR inhibition. Loss of PTEN is a common fact in many cancer types like brain, prostate and breast cancers (Li et al. 1997).

\section{AUTOPHAGY IN CANCER}

Autophagy has a very tight and complex relationship with cancer. It has been understood as a tumor suppressor mechanism by preventing the tumorigenic process onset through the degradation of damaged organelles and toxic proteins. Once the tumor is formed, however, it has been linked to a tumor promoting mechanism by providing the recycling substrate to cancer cell survival and selection of resistance mechanisms to therapy (Mathew and White 2011).

Mice with allelic loss of the Beclin-1 gene present impaired autophagy and develop hepatocellular carcinomas in advanced ages, showing that autophagy can also work as a tumor suppressor mechanism (Yue et al. 2003). It was shown that p62 deficiency in autophagy deficient liver prevents the onset of the tumorigenic process (Mathew et al. $2009 \mathrm{~b}$ ). The levels of p62 are regulated by the autophagic process, since p62 is degraded through it. Interestingly, p62 regulates a survival pathway in response to oxidative stress. In the presence of such stress, the levels of p62 increase. In those circumstances, p62 disrupts the binding of the transcription factor NRF2 with its inhibitor, leading to the activation of survival genes (Villeneuve et al. 2010). When autophagy is impaired, p62 levels are constitutively high, which translates in the 
up-regulation of this survival pathway. Thus, the accumulation of p62 is a very important fact in the impaired autophagy-related tumorigenesis.

Autophagy is activated in tumor cells by many common tumor environment stressors, such as hypoxia, growth factor deprivation and starvation, and is associated with survival. The inhibition of autophagy genes results in cell death of tumor cells mainly present in hypoxic regions (KarantzaWadsworth et al. 2007).

Autophagy is also activated in response to many therapy agents as a survival mechanism (Table SI - Supplementary Material). For example, it has been shown that 5-fluorouracil (5-FU), which is a first-line drug for colorectal cancer, induces autophagy in colorectal cancer cells. The combination of chloroquine diphosphate (CQ), an autophagy inhibitor, and 5-FU resulted in the inhibition of 5-FU-induced autophagy and a significant enhancement in the 5-FU-induced inhibition of colon cancer growth both in vitro and in vivo (Sasaki et al. 2012). Interestingly, treatment with autophagy inhibitors increase the cell death induced by bevacizumab (AVASTIN ${ }^{\circledR}$ ), a monoclonal antibody that inhibits the biologic activity of vascular endothelial growth factor (VEGF), in hepatocellular carcinomas (Guo et al. 2013). Therefore, strategies to inhibit autophagy in an attempt to increase the response to therapy are feasible, and mostly, desirable (Amaravadi et al. 2011) (Figure 2). The lysosomotropic anti-malarial agent hydroxychloroquine (HCQ), which blocks the degradation of autophagic content through inhibition of lysosomal function is being clinically tested (White and DiPaola 2009). Phase I and II clinical trials combining HCQ with therapeutic agents such as docetaxel, gemcitabine and tamoxifen were carried out in prostate, breast and pancreatic cancer patients (Swampillai et al. 2012).

In summary, autophagy plays a similar role in tumor cells as it does in normal cells, coping cell survival to stress stimulus. Initially, defects in the autophagic process might facilitate the acquisition of malignant features by healthy cells. Later on,

a

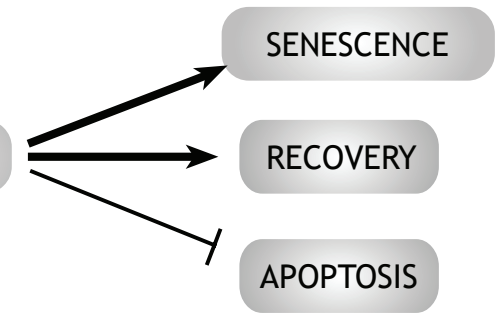

CELL DEATH

b

AUTOPHAGY

STRESS

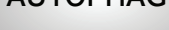

APOPTOSIS
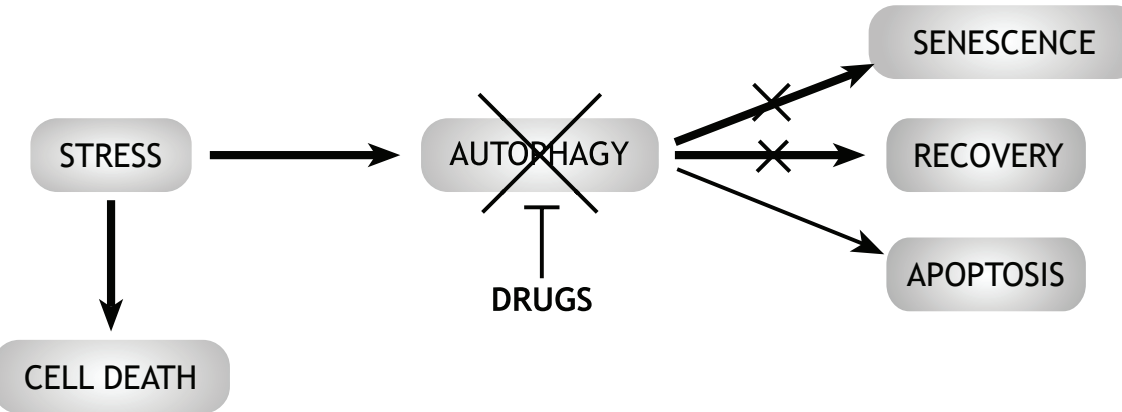

Figure 2 - Interplay among autophagy, apoptosis, and senescence. Effects of a cell stress in control conditions (a) or when autophagy is blocked (b). 
once malignancy is established, the restoration of proficient autophagic responses may be essential to support the survival, proliferation and growth of cancer cells in the presence of adverse microenvironmental conditions (reviewed in Galluzzi et al. 2015b). Since tumor cells encounter greater stress, the dependence on autophagy may be more substantial. Indeed, autophagy localizes in tumors hypoxic regions most distal from blood vessels, where it supports tumor cell survival (Degenhardt et al. 2006, Karantza-Wadsworth et al. 2007, Mathew et al. 2009a, 2007). Thus, the autophagy dependence of malignant tumor cells, together with the fact that many therapeutic agents induce autophagy (Table SI), the combination of those agents with different autophagy inhibitors, probably will provide a therapeutic window for some cancer types. Indeed, a long list of Phase I and II clinical trials with combining therapeutic agents with different autophagy inhibitors, such as bafilomycin A1, 3-MA and CQ, were already summarized in recent reviews (Sui et al. 2013, Jiang and Mizushima 2014).

\section{APOPTOSIS AND AUTOPHAGY}

The complex connection between autophagy and apoptosis is observed in many levels, and several stimuli can induce both processes (Figure 2). In many cases, autophagy functions as a survival mechanism through which the cells adapt to such conditions, escaping cell death by apoptosis. However, in other situations, autophagy leads to cell death, by autophagic cell death (or type II cell death) (Baehrecke 2005). According to the Nomenclature Committee on Cell Death (NCCD), autophagic cell death is described as a cell death that can be blocked by autophagy pathway inhibitors (Baehrecke 2005), and should not be mistaken by apoptosis that may be preceded by autophagy.

The general idea is that stress often stimulates an autophagic response, if the level of stress is not lethal, but it also stimulates apoptotic response when stress exceeds a critical threshold. In many cases, autophagy constitutes a strategy to adapt and survive with stress. If apoptotic response starts, however, autophagy can be inhibited, in part due to the caspase-mediated cleavage of essential autophagy proteins (Marino et al. 2014). Recent molecular biology studies have shed light on common regulators to both apoptosis and autophagy, which helps to explain the nature of this relationship.

Mice deficient on the pro-apoptotic effector proteins Bax and Bak $\left(\mathrm{Bax}^{-/}, \mathrm{Bak}^{-/}\right)$are resistant to apoptosis induced by DNA damaging agents, as it would be expected. When embryonic fibroblasts from those mice are treated with etoposide (topoisomerase type II inhibitor), they undergo massive autophagy and present delayed autophagic cell death. This same phenotype in the presence of DNA damaging agents is not found in other apoptotic resistant backgrounds like caspase $9^{-1-}$ and Apafl $^{-1}$, suggesting a mechanistic role for Bax and Bak to inhibit autophagic cell death induced in those conditions (Shimizu et al. 2004). Moreover, the inhibition of caspases activity through the treatment with Z-VAD increases monocytes and macrophages autophagic cell death in response to lipopolysaccharide treatment. Interestingly, this cell death was prevented by the use of interference RNA targeting the autophagy inductor Beclin-1 (Xu et al. 2006).

Autophagy can also attenuate cell death by selectively reducing the abundance of pro-apoptotic proteins in the cytosol. Autophagy can selectively target specific proteins that have been ubiquitylated; this modification enables them to interact with autophagy receptors, a series of adaptors, including p62, that bind both ubiquitylated substrates and LC3 (Shaid et al. 2013). As an example, colon cancer cells lacking the pro-apoptotic protein BAX are resistant to TRAIL (TNF-related apoptosisinducing ligand)-induced cell death unless autophagy is inhibited. This might be explained 
by the selective removal of caspase 8 activated by autophagy (Hou et al. 2010, Marino et al. 2014).

Interestingly, cell treatment with $\mathrm{BH} 3$ mimetics, as ABT 737, induced autophagy-preceding apoptosis (Malik et al. 2011). Beclin-1 has been identified as part of the BH3-only group of proteins. When BH3-only proteins are activated, they competitively disrupt the interaction between Beclin-1 and BCL2, letting Beclin-1 free to complex with Vps34 to induce autophagy (Maiuri et al. 2007). In this context, the BCL2 subcellular localization is determinant for the stimulus outcome. BCL2 can be found in endoplasmic reticulum (ER) or in mitochondria, and only those on the ER can physically interact and inhibit Beclin-1. Thus, it can be inferred that BCL2 localized in ER is both anti-apoptotic and anti-autophagic, whereas BCL2 localized in mitochondria is only anti-apoptotic. Therefore, the balance between the $\mathrm{BH} 3$-only proteins that bind and inhibit BCL2 in the ER or in mitochondria, dictates the balance between autophagy and apoptosis (Yanagisawa et al. 2003). In summary, anti-apoptotic proteins from the BCL2 family usually inactivate Vps34-Beclin-1 complex preventing nucleation of isolation membrane. BCl2-Beclin-1 binding inhibits the pro-autophagic function of Beclin-1 but does not interfere with the anti-apoptotic activity of the BCL2 family. So far by exception of BH3-only protein BIM (BCL2-interacting mediator of cell death), which also prevents autophagy, the $\mathrm{BH} 3$-only proteins disrupt Beclin-1-BCL2 interaction and enables Beclin-1 to increase autophagic activity. Moreover, kinases such as Death associated protein kinase (DAPK), JUN N-terminal kinase (JNK) and protein kinase D (PKD) can phosphorylate Beclin1, Vps34 or BIM, disrupting their inhibitory interaction with BCL2 increasing autophagy (reviewed in Marino et al. 2014).

In addition, several in vivo studies suggest that the inhibition of ATG genes causes apoptotic cell death. Targeted knockdown of ATG5 in T cells leads to death of the mature $\mathrm{T}$ cell, suggesting an increase in apoptosis induced by the T-cell receptor stimulation (Pua et al. 2007). The specific and simultaneous knockdown of neuronal ATG5 and $A T G 7$ leads to an accumulation of cytoplasmic bodies and neuronal apoptosis, culminating with neurodegeneration. A possible explanation for this outcome is that, as non-dividing cells, neurons are not able to reduce its amount of waste protein aggregates in each cell division, and so, they rely mainly on autophagy for this homeostatic function (Komatsu et al. 2006). Those results point out that basal autophagy is fundamental to neuron homeostasis.

Additional link between apoptotic and autophagic response can be found in the unusual externalization of large autophagic vacuoles. Nutrient deprivation of endothelial cells evokes unconventional secretion of autophagic vacuoles through plasma membrane. Induction of autophagy was followed by indices of an apoptotic response; caspase 3 modulations in endothelial cells prevented the secretion of autophagic content, but not autophagy process, and, as expected, reduced nuclear markers of apoptosis (Sirois et al. 2012). Those results suggested caspase 3 activation, apart from being an effector of the apoptotic process, may also plays a role in the release of autophagy vacuoles. Whether this release is another intercellular communication device or a way that contributes to the reduction of cell volume associated with caspase-dependent apoptotic cell death remains to be explored.

In most cases, in stressful conditions, such as in the presence of chemotherapy treatment, autophagy appears to work as a cytoprotective pathway, as already mentioned earlier in this review. Mitochondria play a very important role in apoptosis. Thus, mitophagy (mitochondrial autophagy) of mitochondria that are undergoing mitochondrial outer membrane permeabilization (MOMP) might be a relevant mechanism by which autophagy inhibits stress-induced apoptosis (Colell 
et al. 2007). In some cases, autophagy-promoted survival is accompanied by stress-induced cell cycle arrest. Nutrient deprivation activates AMP kinase, which can induce autophagy, as mentioned here, but it also induces p27 (CDK inhibitor). In this scenario, nutrient deprivation induces cell cycle arrest and autophagy as a survival response, avoiding apoptosis (Liang et al. 2007). Moreover, in the presence of whole body gamma-irradiation, autophagy protects the hematopoietic system against nuclear radiation injury by intensifying DNA damage repair pathways, removing reactive oxygen species and inhibiting apoptosis (Lin et al. 2015). It is possible that such mechanism could also protect cancer cells. Therefore, further understanding of the relationship between DNA damage-induced apoptosis and autophagy is not only relevant, but also urgent to cancer treatment.

Interestingly, the first tumor suppressor described, $\mathrm{RB}$, has been implicated in controlling apoptosis and autophagy.

\section{RB PATHWAY}

In the $70 \mathrm{~s}$, through statistical studies of the retinoblastoma childhood cancer, Knudson postulat- ed the two-hit hypothesis, where two mutational events would be necessary for the retinoblastoma development. In the hereditary cases, one of the mutations would be inherited in the germline cells, and the other one would occur in somatic cells. In the non-hereditary cases, both mutational events would occur throughout life, culminating with the retinoblastoma development (Knudson 1971). $R B-1$ gene encodes a 928 amino acids nuclear- cytoplasmatic phosphoprotein. Together with p107 and $\mathrm{p} 130, \mathrm{RB}$ is part of the pocket proteins family, which can bind to the E2F transcription factor family (Dyson 1998).

$\mathrm{RB}$ is a major cell cycle regulator, and exerts its function mainly by controlling E2F1 activity. For the G1/S phase transition to occur, RB must be inactivated by hyperphosphorylation, which promotes the disassembly of transcriptional repressive mechanisms mediated by $\mathrm{RB}$ in $\mathrm{E} 2 \mathrm{~F}$ responsive genes. Thus, resulting in transcription of many genes needed for cell cycle progression, such as cyclin E and Proliferating Cell Nuclear Antigen (PCNA) (Figure 3) (Weinberg 1995).

$\mathrm{RB}$ phosphorylation is regulated throughout the cell cycle by cyclin/CDK complexes, namely

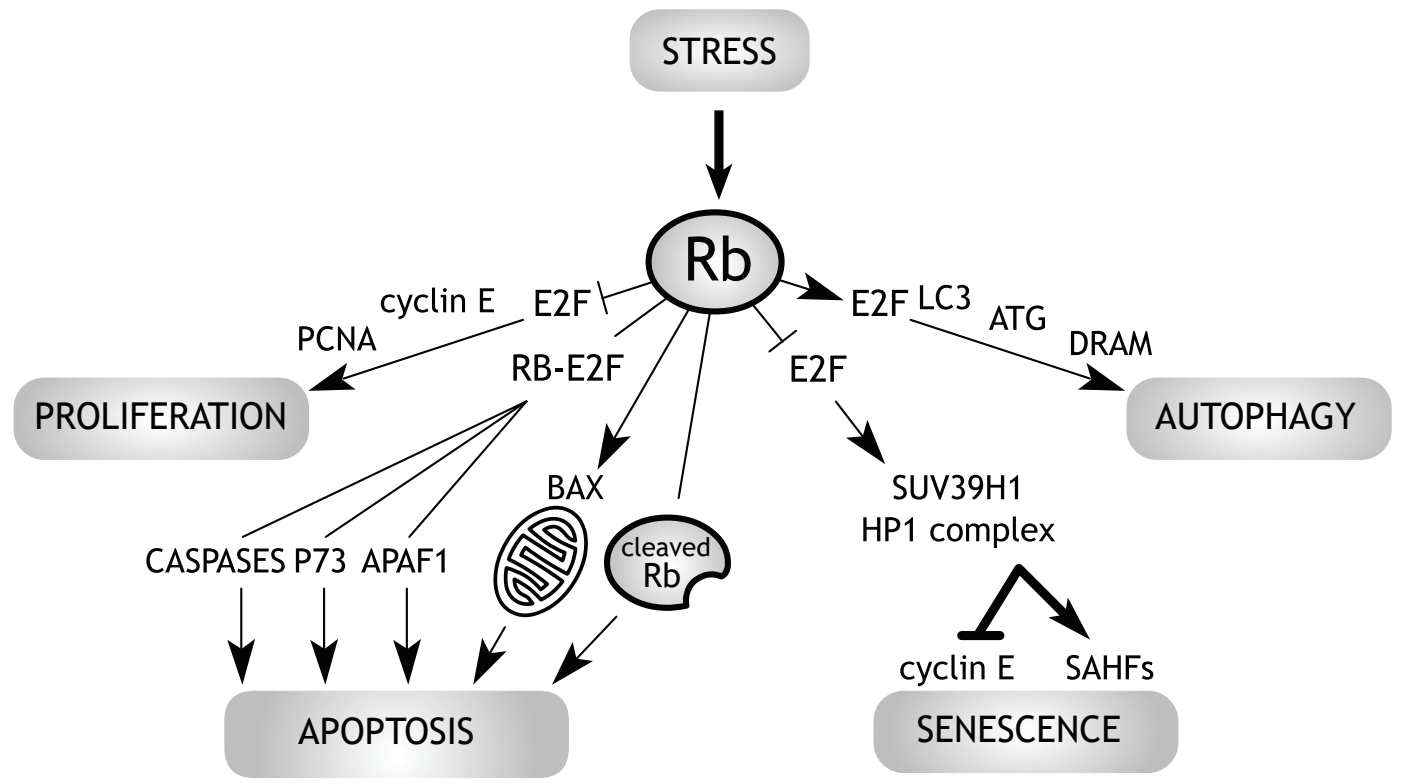

Figure 3 - RB pathways in proliferation, apoptosis, autophagy and senescence. 
cyclin D-CDK4/6 and by PP1 (protein phosphatase 1). In the presence of a stressful stimulus, like nutrient starvation, RB can be dephosphorylated by the action of CDK inhibitors, such as p16, which will inhibit cell cycle transition (Kolupaeva and Janssens 2013).

Alterations in the RB pathway are present in about $70 \%$ of all tumor types. Interestingly, the way by which the pathway is altered varies between tumor types. In some cases, like small cell lung cancer (SCLC) and bladder cancer, the loss of RB expression itself is the most common alteration found in the pathway (more than $90 \%$ of SCLC and up to $70 \%$ of bladder cancer cases). In other tumor types such as colorectal, pancreatic, breast and liver cancer, most of the alterations found in the pathway are in upstream components (overexpression of cyclin D1 or loss of expression of the CDK inhibitor p 16 - up to $80 \%$ in colorectal cancer, up to $90 \%$ in pancreatic cancer, up to $70 \%$ in breast cancer and up to $80 \%$ in liver cancer) (Knudsen and Knudsen 2008). In those cases, RB is still present in cancer cells, but inactivated in its cell cycle blocking function by hyperphosphorylation. Thus, understanding RB functions besides cell cycle blockage is important regarding the study of those cancers.

The simplistic view that E2F is released during the cell cycle by hyperphosphorylated RB has been revised. During cell cycle progression, a fraction of RB-E2F complexes persists even when RB is phosphorylated. This result helped understanding why during proliferation in normal conditions, E2F1-inducible apoptotic genes such as apoptotic peptidase activating factor-1 (APAF-1), caspases and $\mathrm{p} 73$ are not expressed along S-phase, since at least a fraction of RB1-E2F1 complexes persist at the repressing promoters of E2F1 apoptotic genes (Dick and Rubin 2013, Attardi and Sage 2013). In the current view, RB is a scaffold for multiple protein interactions, involved in distinct physiological processes. Most of these roles are mediated by transcriptional regulation exerted both by direct interactions with transcription factors as well as by recruiting co-repressors/activators to sequence-specific transcription factors (Talluri and Dick 2012). Therefore, RB pathway is relevant not only in cell cycle progression, but also for apoptosis and autophagy.

\section{RB FUNCTIONS}

Apart from regulating cell cycle transition, many other important roles have been addressed to RB, such as differentiation, senescence, apoptosis and, recently, autophagy. RB makes complex not only with E2F, but also with different partners that mediate positive and negative regulation of transcription. For example, during differentiation, transcription factors are activated in the presence of RB, such as MyoD during myogenesis, CBFA1/ Runx2 during osteogenesis (Thomas et al. 2001) and C/EBP and NF-IL6 during adipogenesis (Chen et al. 1996a, b,).

Senescence is a stable form of cell cycle arrest induced by stressful stimuli like oncogene activation and DNA damage or by telomere attrition, called replicative senescence (Campisi 2001). Senescence has been linked to a cell state resistant to several kinds of stress conditions. Accumulation of autophagosomes is observed in senescent fibroblasts suggesting autophagy is required for tumor senescence (Figure 2). The senescent cell is not only resistant to cell death but show a secretory phenotype, called the senescence-associated phenotype (SASP), which contributes to tumor progression. This phenotype includes the secretion of many factors such as interleukines (IL8, IL6 and IL7) and metalloproteinases (MMP2 and MMP3), and thus has the potential to create a malignant microenvironment (Coppe et al. 2010).

When cells enter in senescent state, they stop expressing replication genes. Narita et al. 2003 showed that senescent cells accumulate a distinct heterochromatic pattern, called the senescence 
associated heterochromatic foci (SAHF), which coincides with the recruitment of $\mathrm{RB}$ and heterochromatin proteins to E2F-responsive genes promoters and the permanent silencing of essential replication genes (Narita et al. 2003). SAHFs are linked to transcriptional repression of proliferative genes as they become enclosed in these foci leading to stable silencing. These heterochromatic foci are detected by a preferential DNA dye binding or by the presence of heterochromatin protein-1 (HP1). HP1 binds to heterochromatin-associated histone modifications, including histone $\mathrm{H} 3$ that is methylated at Lysine 9 by Histone-lysine N-methyltransferase (Suv39h1). A complex of RB, Suv39h1 and HP1 was shown to repress the cyclin E promoter. In agreement with RB role in inducing and keeping senescence state, acute loss of RB in senescent mouse embryonic fibroblasts (MEFs) results in increased DNA synthesis, cell cycle re-entry and subsequent reversal of cellular senescence (Sage et al. 2003). $R b 1^{-/}$MEF's can arrest with hallmarks of senescence, but they escape and immortalize sooner than control cells expressing RB protein (Dannenberg et al. 2000, Sage et al. 2000). This result remarkably places RB in an essential position in the molecular control of the entrance and maintenance of cellular senescence (Figure 3).

In addition to cell cycle progression and senescence, RB also regulates apoptosis. Homozygous mutant mice $\left(\mathrm{Rbl}^{-/}\right)$embryos are embryonic lethal (Clarke et al. 1992, Jacks et al. 1992, Lee et al. 1992), and show extensive apoptosis in the central and peripheral nervous system and other organs involving different apoptotic mechanisms (Borges et al. 2007, Guo et al. 2001, Simpson et al. 2001). The massive neuronal loss in developing nervous system with $R b$ germline loss-of-function mutations can be explained by placental formation defects (de Bruin et al. 2003). However, acute murine knockout models of $\mathrm{Rb}$ in terminally differentiated neurons in vitro and in vivo reported that acute inactivation of $\mathrm{Rb}$ in postmitotic neurons results in ectopic cell cycle protein expression and neuronal loss without concurrent induction of classical E2f-mediated apoptotic genes, such as Apafl (Andrusiak et al. 2012). These results suggest that terminally differentiated neurons require $\mathrm{Rb}$ for continuous cell cycle repression and survival.

In proliferating cells, the cell cycle arrest induced by RB is anti-apoptotic, since RB-null fibroblasts have a defective DNA-damage induced cell cycle arrest and die by apoptosis (Knudsen et al. 2000). Moreover, restoration of RB in RB1-deficient cells from several cancer types prevented apoptosis induced by ionizing radiation, p53 overexpression, ceramide, and interferon (IFN)- $\gamma$ (Berry et al. 1996, Haas-Kogan et al. 1995, Haupt et al. 1995, McConkey et al. 1996), suggesting RB being antiapoptotic against different cell death inducers. The anti-apoptotic role of RB could be a consequence of the cell cycle arrest in response to stress signals. However, the ectopic expression of a mutated form of $\mathrm{RB}$, which is unable to induce growth arrest, protected RB1 deficient osteosarcoma and breast cancer cells from DNA damage-induced apoptosis (Chau et al. 2006). Therefore, RB1 could be antiapoptotic independent of growth arrest, what could be through the direct inhibition of apoptotic genes (Indovina et al. 2015).

Moreover, RB is cleaved by caspases during the TNF- $\alpha$ induced apoptotic process, and importantly, a caspase non-cleavable form of RB leads to apoptosis resistance in those conditions (Chau et al. 2002), showing that RB has a role also in the apoptosis induced by the extrinsic apoptotic pathway (Figure 3). It is worth to mention that at least for RB cleavage by caspases, apoptosis regulation is not a consequence to cell cycle arrest disruption, since the mutant caspase resistant form of RB does not interfere with the cell cycle regulation (Chau et al. 2002). RB is not an absolute prerequisite for apoptosis, but it can be a crucial 
step for certain apoptotic events, depending on both the cell type and the nature of the death inducers.

In some cases, however, RB can have a proapoptotic function by positively regulating the transcription of pro-apoptotic E2F responsive genes, such as p73 and/or caspase 7 (Ianari et al. 2009), showing that the role of RB in apoptosis has to be considered in a contextual basis (Figure 3). DNA damage posttranslational modifications have also been shown relevant to pro-apoptotic function of RB. After DNA damage, RB is dephosphorylated at $\mathrm{CDK}$ target sites, however, damage-activated kinases (ataxia-telangiectasia mutated-ATM- and checkpoint kinase 1/2-CHEK1/2) phosphorylate $\mathrm{RB}$ and/or E2F. RB-E2F1 are also acetylated, and methylated, and recruits histone acetyltransferase p300/CBP-associated factor (P/CAF) forming a transcriptionally active complex that can induce E2F1 apoptotic genes and repress cell cycle genes (Figure 3) (Dick and Rubin 2013, Munro et al. 2012). Moreover, independent of its role as a transcriptional regulator, it was shown that $\mathrm{RB}$ directly activates the apoptosis regulator BAX at the mitochondria and promotes cell death (Hilgendorf et al. 2013). Altogether, these data suggests that the anti- and pro-apoptotic roles of RB might depend on the cell context. In line with the idea that the role of $\mathrm{RB}$ in apoptosis has to be considered in a contextual basis, unpublished data from our group suggest that RB knockdown has different outcomes according to the cytotoxic treatment and cell line used (Borges, Rodrigues and Soletti). RB knockdown could increase cisplatin-induced apoptosis, measured by caspase 3 activation and the picnotic nuclei percentage; but decreased 5-FU induced cell death in esophagus carcinoma cell lines. In addition, similar results were obtained when RB pathway was modulated. CDK inhibitor co-treatment (roscovitine or flavopiridol) was able to increase cisplatin-induced apoptosis. In contrast, 5-FU-induced cell death was reduced by co-treatment with the CDK inhibitors. In addition, either RB knockdown or CDK inhibitors treatments increased TNF-induced apoptosis in cell lines of esophagus adenocarcinoma, whereas had no effect in the carcinomas. Therefore, these results suggest that interfering with RB pathway could increase or decrease the apoptosis threshold according to specific stress conditions and cancer type.

\section{RB AND AUTOPHAGY}

Some works have described a role for RB-E2F pathway in the autophagic process. E2F 1 can induce the expression of autophagy genes such as LC3, ATG1, and damage-regulated autophagy modulator (DRAM) (Polager et al. 2008). Moreover, E2F1 lacking transcriptional activity domain has been showed to induce autophagy, what suggests that expression of autophagy genes might not be the only way of E2F-RB pathway to regulate autophagy (Garcia-Garcia et al. 2012) (Figure 3). Indeed, Jiang et al. (2010) have shown evidences that suggest that $\mathrm{RB}$ is required for the autophagy induction that accompanies CDK inhibitor mediated cell cycle arrest. When RB was transduced in a panel of RB defective cell lines, LC3-II conversion and ultrastructural autophagy phenotype were observed, indicating that the exogenous RB induces autophagy in those cell lines. This autophagy induction was accompanied by the expression of autophagy-related genes like Beclin-1 and by the down-regulation of BCL2. Moreover, by treating p16 or p27 null-cell lines with CDK inhibitors, the authors showed an induction of autophagy, which was abrogated by RB knockdown, showing that CDK inhibitor induced autophagy is dependent on RB. Additionally, they showed that RB binding to E2F is required for this autophagy induction and that when exogenous E2F was transduced together with RB; it resulted in apoptosis induction in spite of autophagy (Jiang et al. 2010). Thus, the authors proposed a mechanism through which the dephosphorylated RB, mediated by CDK inhibitor treatment, increases the levels of E2F linked to RB. 
The lower expression of BCL2, an E2F target, in turn, results in the release of the complex Beclin1-BCL2, which increased autophagic activity of Beclin-1.

In addition, recent work has found that $\mathrm{RB} /$ E2F1 pathway is a novel mediator of autophagy induced by the tumor suppressor Transforming Growth Factor- $\beta$ (TGF $\beta$ ) (Korah et al. 2016). TGF $\beta$ signaling pathways exert tumor suppressor effects in normal cells and early carcinomas. As tumors develop and progress, these protective and cytostatic effects of TGF $\beta$ are often lost. TGF $\beta$ signaling then switches to promote cancer progression, invasion, and tumor metastasis (Lebrun 2012). TGF $\beta$ activates autophagy in various cancer cell lines and these effects are dependent of E2F1 and RB, as multiple autophagy-related genes that function at various stages in this autophagy process seem to be regulated by $\mathrm{RB} / \mathrm{E} 2 \mathrm{~F} 1$ - dependent transcriptional activation (Korah et al. 2016).

INTERPLAY BETWEEN RB, AUTOPHAGY, SENESCENCE AND APOPTOSIS

Recently, our group showed that RB expression is essential for the continuation of the etoposideinduced autophagic flux, as well as it works as an anti-apoptotic factor. By knocking down RB in glioblastoma cells, we observed an increase in etoposide-induced DNA double strand breaks, caspase 3 cleavage, p53-activation and apoptosis. These effects were accompanied by an impaired autophagic flux, characterized by a dysfunctional autophagosome-lysosome fusion and accumulation of p62 (Biasoli et al. 2013). We also observed that the increased activation of p53 was followed by an increase in DRAM activation, which can help explain the induction of autophagic flux by etoposide and that might have been blocked in its last steps when RB was knocked down in consequence of the increased apoptotic rate. Recently, in a similar study, knockdown of RB during treatment with cisplatin inhibited autophagy and improved cisplatin-induced apoptosis (Liu et al. 2016).

$\mathrm{RB}$ seems to have a role in the last steps of the autophagic flux. Huang et al. (2007) showed that RB cleavage is necessary for Bid cleavage in the TNF- $\alpha$ induced type II apoptosis. Consistent with this notion, inhibition of V-ATPase with bafilomycin A1, which interfere with acidification of lysosomes and hampers its fusion to autofagosomes and endosomos, restores Bid cleavage and apoptosis in caspase resistant RB cell lines. In mice with a mutant non-cleavable form of RB, Bid cleavage does not occur. Interestingly, the autophagosomes can work as a platform for the DISC-induced activation of caspase 8 through the extrinsic pathway (Huang et al. 2007). It might be the case that RB cleavage impairs the fusion between autophagosomes and lysosomes, leading to autophagosomes accumulation and increased levels of caspase 8 activation and apoptosis.

Interestingly, senescence and autophagy exist as parallel processes. In oncogenic-induced senescence, which is RB-dependent, autophagy activity is increased, monitored by the activation of LC3-II. Autophagy contributes to cell cycle arrest and production of senescence-associated interleukins, allowing protein degradation to feed raw materials directly into protein synthesis for the SASP (Narita et al. 2011, Young et al. 2009). Moreover, the inhibition of autophagy delays the senescence process (Young et al. 2009). In other studies, however, senescence was independent of autophagy and could occur even when autophagy was suppressed (Goehe et al. 2012, Young et al. 2009).

\section{CONCLUSIONS}

The interplay between autophagy, senescence and apoptosis is a complex subject, and it can affect the fate of a cell under a stress, as the response of cancer cells to therapy. Autophagy increases the threshold of stress required for the induction of cell death 
by several mechanisms, such as selective removal of damaged, potentially apoptosis-inducing mitochondria and by reducing the abundance of pro-apoptotic proteins in the cytosol. It has also been implicated in cancer resistance to cytotoxic drugs and in the senescence process; the cell cycle arrested state that is linked to natural resistance to stress, and during which the cell secretes tumor microenvironment contributing factors. The identification of biomarkers that reflect autophagy status, as well as the molecular switches among autophagy, senescence and apoptosis processes will have to be developed in order to design better therapies for patients.

Most sporadic cancers have RB inactivated due to defects in the pathways that regulate its phosphorylation rather than by mutations. RB is now viewed as a multifunctional protein, being a regulator not only for senescence, differentiation and cell cycle, but also, more recently for apoptosis and autophagy. Recent findings in the literature have shown that RB pathway can regulate autophagy in many levels of the process, as well as the molecular interplay between autophagy and apoptosis. Particularly RB contribution on apoptosis depends on both the cell type and the nature of the death inducers and its function can be modulated by several post-translational modifications. RB inhibition can confer a proliferative advantage to cells, but the apoptosis resulting from its loss may affect cancer growth and, perhaps, interfere with other cellular resistance abilities to respond to stress such as induction of senescence and autophagy. More studies are needed in order to fully understand in the molecular level, how the pathways operate to regulate the switches among those processes.

A recent review summarized several studies on patients with different cancer types, suggesting that RB status affects tumor sensitivity and clinical outcome (Indovina et al. 2015). RB1 deficiency seems to be associated to improved cytotoxic response to DNA damage agents for some cancer subtypes, and it also limits the effect of hormone and anti-proliferative signaling therapies (Indovina et al. 2015). These findings suggest that RB might be a crucial target for anticancer strategies, but further studies are necessary.

A better knowledge of how to interfere with RB pathway at the level of the interplay between proliferation, autophagy and apoptosis will enable the understanding of how a specific alteration found in RB pathway can affect the fate of cancer cells. Altogether, this review emphasizes the need to study RB pathway and others that regulate proliferation, autophagy, senescence and apoptosis processes with the expectation of better strategies of drug combinations for cancer treatment.

\section{ACKNOWLEDGMENTS}

Deborah Biasoli, João M.A. Delou and Helena L. Borges are are supported by the Conselho Nacional de Desenvolvimento Científico e Tecnológico (CNPq), by the Coordenação de Aperfeiçoamento de Pessoal de Nível Superior (CAPES), the Fundação Carlos Chagas Filho de Amparo à Pesquisa do Estado do Rio de Janeiro (FAPERJ), and by the Fundação do Câncer do Rio de Janeiro, Brazil. We thank Dr. Rossana Colla Soletti for constructive comments of the manuscript.

\section{REFERENCES}

AMARAVADI RK, LIPPINCOTT-SCHWARTZ J, YIN XM, WEISS WA, TAKEBE N, TIMMER W, DIPAOLA RS, LOTZE MT AND WHITE E. 2011. Principles and current strategies for targeting autophagy for cancer treatment. Clin Cancer Res 17: 654-666.

ANDRUSIAK MG, VANDENBOSCH R, PARK DS AND SLACK RS. 2012. The retinoblastoma protein is essential for survival of postmitotic neurons. J Neurosci 32: 1480914814.

ATTARDI LD AND SAGE J. 2013. RB goes mitochondrial. Genes Dev 27: 975-979.

AVERY-KIEJDA KA ET AL. 2011. P53 in human melanoma fails to regulate target genes associated with apoptosis and the cell cycle and may contribute to proliferation. BMC Cancer 11: 203. 
BAEHRECKE EH. 2005. Autophagy: dual roles in life and death? Nat Rev Mol Cell Biol 6: 505-510.

BAREFORD MD ET AL. 2011. Sorafenib enhances pemetrexed cytotoxicity through an autophagy-dependent mechanism in cancer cells. Cancer Res 71: 4955-4967.

BERRY DE, LU Y, SCHMIDT B, FALLON PG, O'CONNELL C, HU SX, XU HJAND BLANCK G. 1996. Retinoblastoma protein inhibits IFN-gamma induced apoptosis. Oncogene 12: 1809-1819.

BIASOLI D, KAHN SA, CORNELIO TA, FURTADO M, CAMPANATI L, CHNEIWEISS H, MOURA-NETO V AND BORGES HL. 2013. Retinoblastoma protein regulates the crosstalk between autophagy and apoptosis, and favors glioblastoma resistance to etoposide. Cell Death Dis 4: e767.

BIASOLI D, SOBRINHO MF, DA FONSECA AC, DE MATOS DG, ROMAO L, DE MORAES MACIEL R, REHEN SK, MOURA-NETO V, BORGES HL AND LIMA FR. 2014. Glioblastoma cells inhibit astrocytic p53expression favoring cancer malignancy. Oncogenesis 3 : e123.

BILIR A, ALTINOZ MA, ERKAN M, OZMEN V AND AYDINER A. 2001. Autophagy and nuclear changes in FM3A breast tumor cells after epirubicin, medroxyprogesterone and tamoxifen treatment in vitro. Pathobiology 69: 120-126.

BJORKOY G, LAMARK T, BRECH A, OUTZEN H, PERANDER M, OVERVATN A, STENMARK H AND JOHANSEN T. 2005. p62/SQSTM1 forms protein aggregates degraded by autophagy and has a protective effect on huntingtin-induced cell death. J Cell Biol 171: 603-614.

BOATRIGHT KM ET AL. 2003. A unified model for apical caspase activation. Mol Cell 11: 529-541.

BORGES HL, HUNTON IC AND WANG JY. 2007. Reduction of apoptosis in Rb-deficient embryos via Abl knockout. Oncogene 26: 3868-3877.

BOSNJAK M ET AL. 2014. Inhibition of mTOR-dependent autophagy sensitizes leukemic cells to cytarabine-induced apoptotic death. PLoS One 9: e94374.

CAMPISI J. 2001. Cellular senescence as a tumor-suppressor mechanism. Trends Cell Biol 11: S27-31.

CHAU BN, BORGES HL, CHEN TT, MASSELLI A, HUNTON IC AND WANG JY. 2002. Signal-dependent protection from apoptosis in mice expressing caspaseresistant Rb. Nat Cell Biol 4: 757-765.

CHAU BN, PAN CW AND WANG JY. 2006. Separation of anti-proliferation and anti-apoptotic functions of retinoblastoma protein through targeted mutations of its A/B domain. PLoS One 1: e82.

CHEN K, SHOU LM, LIN F, DUAN WM, WU MY, XIE X, XIE YF, LI W AND TAO M. 2014a. Artesunate induces G2/M cell cycle arrest through autophagy induction in breast cancer cells. Anticancer Drugs 25: 652-662.
CHEN L, YE HL, ZHANG G, YAO WM, CHEN XZ, ZHANG FC AND LIANG G. 2014b. Autophagy inhibition contributes to the synergistic interaction between EGCG and doxorubicin to kill the hepatoma Hep3B cells. PLoS One 9: e85771.

CHEN PL, RILEY DJ, CHEN-KIANG S AND LEE WH. 1996a. Retinoblastoma protein directly interacts with and activates the transcription factor NF-IL6. Proc Natl Acad Sci USA 93: 465-469.

CHEN PL, RILEY DJ, CHEN Y AND LEE WH. 1996b. Retinoblastoma protein positively regulates terminal adipocyte differentiation through direct interaction with $\mathrm{C} /$ EBPs. Genes Dev 10: 2794-2804.

CLARKE AR, MAANDAG ER, VAN ROON M, VAN DER LUGT NM, VAN DER VALK M, HOOPER ML, BERNS A AND TE RIELE H. 1992. Requirement for a functional Rb-1 gene in murine development. Nature 359: 328-330.

CLUZEAU T, ROBERT G, PUISSANT A, JEAN-MICHEL K, CASSUTO JP, RAYNAUD S AND AUBERGER P. 2011. Azacitidine-resistant SKM1 myeloid cells are defective for AZA-induced mitochondrial apoptosis and autophagy. Cell Cycle 10: 2339-2343.

COLELL A ET AL. 2007. GAPDH and autophagy preserve survival after apoptotic cytochrome c release in the absence of caspase activation. Cell 129: 983-997.

COPPE JP, DESPREZ PY, KRTOLICA A AND CAMPISI J. 2010. The senescence-associated secretory phenotype: the dark side of tumor suppression. Annu Rev Pathol 5: 99-118.

DANNENBERG JH, VAN ROSSUM A, SCHUIJFF L AND TE RIELE H. 2000. Ablation of the retinoblastoma gene family deregulates $\mathrm{G}(1)$ control causing immortalization and increased cell turnover under growth-restricting conditions. Genes Dev 14: 3051-3064.

DE BRUIN A, WU L, SAAVEDRA HI, WILSON P, YANG Y, ROSOL TJ, WEINSTEIN M, ROBINSON ML AND LEONE G. 2003. Rb function in extraembryonic lineages suppresses apoptosis in the CNS of Rb-deficient mice. Proc Natl Acad Sci USA 100: 6546-6551.

DEGENHARDT K ET AL. 2006. Autophagy promotes tumor cell survival and restricts necrosis, inflammation, and tumorigenesis. Cancer Cell 10: 51-64.

DESAI S, LIU Z, YAO J, PATEL N, CHEN J, WU Y, AHN EE, FODSTAD O AND TAN M. 2013. Heat shock factor 1 (HSF1) controls chemoresistance and autophagy through transcriptional regulation of autophagy-related protein 7 (ATG7). J Biol Chem 288: 9165-9176.

DEVARAJAN E ET AL. 2002. Down-regulation of caspase 3 in breast cancer: a possible mechanism for chemoresistance. Oncogene 21: 8843-8851.

DICK FA AND RUBIN SM. 2013. Molecular mechanisms underlying RB protein function. Nat Rev Mol Cell Biol 14: 297-306. 
DING ZB ET AL. 2011. Autophagy activation in hepatocellular carcinoma contributes to the tolerance of oxaliplatin via reactive oxygen species modulation. Clin Cancer Res 17: 6229-6238.

DYSON N. 1998. The regulation of E2F by pRB-family proteins. Genes Dev 12: 2245-2262.

ERTMER A, HUBER V, GILCH S, YOSHIMORI T, ERFLE V, DUYSTER J, ELSASSER HP AND SCHATZL HM. 2007. The anticancer drug imatinib induces cellular autophagy. Leukemia 21: 936-942.

GALLUZZI L ET AL. 2015a. Essential versus accessory aspects of cell death: recommendations of the NCCD 2015. Cell Death Differ 22: 58-73.

GALLUZZI L ET AL. 2015b. Autophagy in malignant transformation and cancer progression. EMBO J 34: 856880.

GARCIA-GARCIA A, RODRIGUEZ-ROCHA H, TSENG MT, MONTES DE OCA-LUNA R, ZHOU HS, MCMASTERS KM AND GOMEZ-GUTIERREZ JG. 2012. E2F-1 lacking the transcriptional activity domain induces autophagy. Cancer Biol Ther 13: 1091-1101.

GE L, ZHANG M AND SCHEKMAN R. 2014. Phosphatidylinositol 3-kinase and COPII generate LC3 lipidation vesicles from the ER-Golgi intermediate compartment. Elife 3: e04135.

GOEHE RW, DI X, SHARMA K, BRISTOL ML, HENDERSON SC, VALERIE K, RODIER F, DAVALOS ARAND GEWIRTZ DA. 2012. The autophagy-senescence connection in chemotherapy: must tumor cells (self) eat before they sleep? J Pharmacol Exp Ther 343: 763-778.

GUO XL ET AL. 2013. Inhibition of autophagy enhances anticancer effects of bevacizumab in hepatocarcinoma. J Mol Med (Berl) 91: 473-483.

GUO Z, YIKANG S, YOSHIDA H, MAK TW AND ZACKSENHAUS E. 2001. Inactivation of the retinoblastoma tumor suppressor induces apoptosis protease-activating factor-1 dependent and independent apoptotic pathways during embryogenesis. Cancer Res 61: 8395-8400.

HAAS-KOGAN DA, KOGAN SC, LEVI D, DAZIN P, T'ANG A, FUNG YK AND ISRAEL MA. 1995. Inhibition of apoptosis by the retinoblastoma gene product. EMBO J 14: 461-472.

HACKER G. 2013. Is there, and should there be, apoptosis in bacteria? Microbes Infect 15: 640-644.

HAN W ET AL. 2011a. EGFR tyrosine kinase inhibitors activate autophagy as a cytoprotective response in human lung cancer cells. PLoS One 6: e18691.

HAN W ET AL. 2011b. Autophagy inhibition enhances daunorubicin-induced apoptosis in K562 cells. PLoS One 6: e28491.

HANAHAN D AND WEINBERG RA. 2011. Hallmarks of cancer: the next generation. Cell 144: 646-674.
HAUPT Y, ROWAN S AND OREN M. 1995. p53-mediated apoptosis in HeLa cells can be overcome by excess pRB. Oncogene 10: 1563-1571.

HERNANDEZ-BREIJO B, MONSERRAT J, ROMAN ID, GONZALEZ-RODRIGUEZ A, FERNANDEZMORENO MD, LOBO MV, VALVERDE AM, GISBERT JP AND GUIJARRO LG. 2013. Azathioprine desensitizes liver cancer cells to insulin-like growth factor 1 and causes apoptosis when it is combined with bafilomycin A1. Toxicol Appl Pharmacol 272: 568-578.

HILGENDORF KI, LESHCHINER ES, NEDELCU S, MAYNARD MA, CALO E, IANARI A, WALENSKY LD AND LEES JA. 2013. The retinoblastoma protein induces apoptosis directly at the mitochondria. Genes \& development 27: 1003-1015.

HOU W, HAN J, LU C, GOLDSTEIN LA AND RABINOWICH H. 2010. Autophagic degradation of active caspase-8: a crosstalk mechanism between autophagy and apoptosis. Autophagy 6: 891-900.

HUANG X, MASSELLI A, FRISCH SM, HUNTON IC, JIANG Y AND WANG JY. 2007. Blockade of tumor necrosis factor-induced Bid cleavage by caspase-resistant Rb. J Biol Chem 282: 29401-29413.

IANARI A, NATALE T, CALO E, FERRETTI E, ALESSE E, SCREPANTI I, HAIGIS K, GULINO A AND LEES JA. 2009. Proapoptotic function of the retinoblastoma tumor suppressor protein. Cancer Cell 15: 184-194.

INDOVINA P, PENTIMALLI F, CASINI N, VOCCA I AND GIORDANO A. 2015. RB1 dual role in proliferation and apoptosis: cell fate control and implications for cancer therapy. Oncotarget 6: 17873-17890.

JACKS T, FAZELI A, SCHMITT EM, BRONSON RT, GOODELL MA AND WEINBERG RA. 1992. Effects of an $\mathrm{Rb}$ mutation in the mouse. Nature 359: 295-300.

JIANG H, MARTIN V, GOMEZ-MANZANO C, JOHNSON DG, ALONSO M, WHITE E, XU J, MCDONNELL TJ, SHINOJIMA N AND FUEYO J. 2010. The RB-E2F1 pathway regulates autophagy. Cancer Res 70: 7882-7893.

JIANG P AND MIZUSHIMA N. 2014. Autophagy and human diseases. Cell research 24: 69-79.

KAMADA Y, FUNAKOSHI T, SHINTANI T, NAGANO K, OHSUMI M AND OHSUMI Y. 2000. Tor-mediated induction of autophagy via an Apg1 protein kinase complex. J Cell Biol 150: 1507-1513.

KANZAWA T, GERMANO IM, KOMATA T, ITO H, KONDO Y AND KONDO S. 2004. Role of autophagy in temozolomide-induced cytotoxicity for malignant glioma cells. Cell Death Differ 11: 448-457.

KARANTZA-WADSWORTH V, PATEL S, KRAVCHUK O, CHEN G, MATHEW R, JIN S AND WHITE E. 2007. Autophagy mitigates metabolic stress and genome damage in mammary tumorigenesis. Genes Dev 21: 1621-1635. 
KIM J, KUNDU M, VIOLLET B AND GUAN KL. 2011. AMPK and mTOR regulate autophagy through direct phosphorylation of Ulk1. Nat Cell Biol 13: 132-141.

KIPPS TJ ET AL. 2015. A phase 2 study of the BH3 mimetic BCL2 inhibitor navitoclax (ABT-263) with or without rituximab, in previously untreated B-cell chronic lymphocytic leukemia. Leuk Lymphoma 56: 2826-2833.

KIRSCH DG AND KASTAN MB. 1998. Tumor-suppressor p53: implications for tumor development and prognosis. J Clin Oncol 16: 3158-3168.

KLIONSKY DJ. 2005. The molecular machinery of autophagy: unanswered questions. J Cell Sci 118: 7-18.

KLIONSKY DJ ET AL. 2011. A comprehensive glossary of autophagy-related molecules and processes (2nd edition). Autophagy 7: 1273-1294.

KLIONSKY DJ ET AL. 2003. A unified nomenclature for yeast autophagy-related genes. Dev Cell 5: 539-545.

KNOX JJ, CHEN XE, FELD R, NEMATOLLAHI M, CHEIKEN R, POND G, ZWIEBEL JA, GILL S AND MOORE M. 2008. A phase I-II study of oblimersen sodium (G3139, Genasense) in combination with doxorubicin in advanced hepatocellular carcinoma (NCI \# 5798). Invest New Drugs 26: 193-194.

KNUDSEN ES AND KNUDSEN KE. 2008. Tailoring to RB: tumour suppressor status and therapeutic response. Nat Rev Cancer 8: 714-724.

KNUDSEN KE, BOOTH D, NADERI S, SEVERCHRONEOS Z, FRIBOURG AF, HUNTON IC, FERAMISCO JR, WANG JY AND KNUDSEN ES. 2000. RB-dependent S-phase response to DNA damage. Mol Cell Biol 20: 7751-7763.

KNUDSON JR AG. 1971. Mutation and cancer: statistical study of retinoblastoma. Proc Natl Acad Sci USA 68: 820823.

KOLUPAEVA V AND JANSSENS V. 2013. PP1 and PP2A phosphatases--cooperating partners in modulating retinoblastoma protein activation. FEBS J 280: 627-643.

KOMATSU M ET AL. 2006. Loss of autophagy in the central nervous system causes neurodegeneration in mice. Nature 441: 880-884.

KORAH J, CANAFF L AND LEBRUN JJ. 2016. The Retinoblastoma Tumor Suppressor Protein ( $p R b) / E 2$ Promoter Binding Factor 1 (E2F1) Pathway as a Novel Mediator of Transforming Growth Factor-beta (TGFbeta)Induced Autophagy. J Biol Chem 291(5): 2043-2054.

LAMBERT JM, GORZOV P, VEPRINTSEV DB, SODERQVIST M, SEGERBACK D, BERGMAN J, FERSHT AR, HAINAUT P, WIMAN KG AND BYKOV VJ. 2009. PRIMA-1 reactivates mutant $\mathrm{p} 53$ by covalent binding to the core domain. Cancer Cell 15: 376-388.

LEBRUN J-J. 2012. The Dual Role of TGF in Human Cancer: From Tumor Suppression to Cancer Metastasis. ISRN Molecular Biology 2012: 28.
LEE EY, CHANG CY, HU N, WANG YC, LAI CC, HERRUP K, LEE WH AND BRADLEY A. 1992. Mice deficient for $\mathrm{Rb}$ are nonviable and show defects in neurogenesis and haematopoiesis. Nature 359: 288-294.

LI DD ET AL. 2012. The inhibition of autophagy sensitises colon cancer cells with wild-type p53 but not mutant p53 to topotecan treatment. PLoS One 7: e45058.

LI J, HOU N, FARIED A, TSUTSUMI S AND KUWANO H. 2010. Inhibition of autophagy augments 5-fluorouracil chemotherapy in human colon cancer in vitro and in vivo model. Eur J Cancer 46: 1900-1909.

LI J ET AL. 1997. PTEN, a putative protein tyrosine phosphatase gene mutated in human brain, breast, and prostate cancer. Science 275: 1943-1947.

LIANG J ET AL. 2007. The energy sensing LKB1-AMPK pathway regulates $\mathrm{p} 27$ (kip1) phosphorylation mediating the decision to enter autophagy or apoptosis. Nat Cell Biol 9: 218-224.

LIANG XH, JACKSON S, SEAMAN M, BROWN K, KEMPKES B, HIBSHOOSH H AND LEVINE B. 1999. Induction of autophagy and inhibition of tumorigenesis by beclin 1. Nature 402: 672-676.

LIN W ET AL. 2015. Autophagy confers DNA damage repair pathways to protect the hematopoietic system from nuclear radiation injury. Sci Rep 5: 12362.

LIU D, YANG Y, LIU Q AND WANG J. 2011. Inhibition of autophagy by 3-MA potentiates cisplatin-induced apoptosis in esophageal squamous cell carcinoma cells. Med Oncol 28: 105-111.

LIU X, SUN K, WANG H AND DAI Y. 2016. Knockdown of retinoblastoma protein may sensitize glioma cells to cisplatin through inhibition of autophagy. Neurosci Lett 620: $137-142$.

LUJAMBIO A ET AL. 2013. Non-cell-autonomous tumor suppression by p53. Cell 153: 449-460.

MAIURI MC ET AL. 2007. Functional and physical interaction between Bcl-X(L) and a BH3-like domain in Beclin-1. EMBO J 26: 2527-2539.

MALIK SA ET AL. 2011. BH3 mimetics activate multiple pro-autophagic pathways. Oncogene 30: 3918-3929.

MALKIN D. 2011. Li-fraumeni syndrome. Genes Cancer 2: 475-484.

MANOV I, POLLAK Y, BRONESHTER R AND IANCU TC. 2011. Inhibition of doxorubicin-induced autophagy in hepatocellular carcinoma Hep3B cells by sorafenib--the role of extracellular signal-regulated kinase counteraction. FEBS J 278: 3494-3507.

MARINO G, NISO-SANTANO M, BAEHRECKE EH AND KROEMER G. 2014. Self-consumption: the interplay of autophagy and apoptosis. Nat Rev Mol Cell Biol 15: 8194.

MATHEW R, KARANTZA-WADSWORTH V AND WHITE E. 2009a. Assessing metabolic stress and autophagy status in epithelial tumors. Methods Enzymol 453: 53-81. 
MATHEW R ET AL. 2009b. Autophagy suppresses tumorigenesis through elimination of p62. Cell 137: 10621075.

MATHEW R, KONGARA S, BEAUDOIN B, KARP CM, BRAY K, DEGENHARDT K, CHEN G, JIN S AND WHITE E. 2007. Autophagy suppresses tumor progression by limiting chromosomal instability. Genes Dev 21: $1367-$ 1381.

MATHEW R AND WHITE E. 2011. Autophagy in tumorigenesis and energy metabolism: friend by day, foe by night. Curr Opin Genet Dev 21: 113-119.

MCCONKEY DJ, GOODRICH D, BUCANA C AND KLOSTERGAARD J. 1996. The human retinoblastoma gene product suppresses ceramide-induced apoptosis in human bladder tumor cells. Oncogene 13: 1693-1700.

MUNRO S, CARR SM AND LA THANGUE NB. 2012. Diversity within the $\mathrm{pRb}$ pathway: is there a code of conduct? Oncogene 31: 4343-4352.

NAKAMURAN, MATSUURAA, WADAY AND OHSUMIY. 1997. Acidification of vacuoles is required for autophagic degradation in the yeast, Saccharomyces cerevisiae. J Biochem 121: 338-344.

NARITA M, NUNEZ S, HEARD E, LIN AW, HEARN SA, SPECTOR DL, HANNON GJ AND LOWE SW. 2003. $\mathrm{Rb}$-mediated heterochromatin formation and silencing of E2F target genes during cellular senescence. Cell 113: 703-716.

NARITA M ET AL. 2011. Spatial coupling of mTOR and autophagy augments secretory phenotypes. Science 332: 966-970.

O'BRIEN S ET AL. 2007. Randomized phase III trial of fludarabine plus cyclophosphamide with or without oblimersen sodium (Bcl-2 antisense) in patients with relapsed or refractory chronic lymphocytic leukemia. J Clin Oncol 25: 1114-1120.

O'BRIEN S ET AL. 2009. 5-year survival in patients with relapsed or refractory chronic lymphocytic leukemia in a randomized, phase III trial of fludarabine plus cyclophosphamide with or without oblimersen. J Clin Oncol 27: 5208-5212.

O'DONOVAN TR, O'SULLIVAN GC AND MCKENNA SL. 2011. Induction of autophagy by drug-resistant esophageal cancer cells promotes their survival and recovery following treatment with chemotherapeutics. Autophagy 7: 509-524.

OLTERSDORF T ET AL. 2005. An inhibitor of Bcl-2 family proteins induces regression of solid tumours. Nature 435: 677-681.

PAILLAS S ET AL. 2012. MAPK14/p38alpha confers irinotecan resistance to TP53-defective cells by inducing survival autophagy. Autophagy 8: 1098-1112.

PAN B, CHEN D, HUANG J, WANG R, FENG B, SONG H AND CHEN L. 2014. HMGB1-mediated autophagy promotes docetaxel resistance in human lung adenocarcinoma. Mol Cancer 13: 165.
PAN X, ZHANG X, SUN H, ZHANG J, YAN MAND ZHANG H. 2013. Autophagy inhibition promotes 5-fluorouraciinduced apoptosis by stimulating ROS formation in human non-small cell lung cancer A549 cells. PLoS One 8: e56679

PAN Y, GAO Y, CHEN L, GAO G, DONG H, YANG Y, DONG B AND CHEN X. 2011. Targeting autophagy augments in vitro and in vivo antimyeloma activity of DNA-damaging chemotherapy. Clin Cancer Res 17: 3248-3258.

PARDO R, LO RÉ A, ARCHANGE C, ROPOLO A, PAPADEMETRIO DL, GONZALEZ CD, ALVAREZ EM, IOVANNA JL AND VACCARO MI. 2010. Gemcitabine induces the VMP1-mediated autophagy pathway to promote apoptotic death in human pancreatic cancer cells. Pancreatology 10: 19-26.

PEPPER C, HOY T AND BENTLEY DP. 1997. Bcl-2/ Bax ratios in chronic lymphocytic leukaemia and their correlation with in vitro apoptosis and clinical resistance. Br J Cancer 76: 935-938.

POLAGER S, OFIR M AND GINSBERG D. 2008. E2F1 regulates autophagy and the transcription of autophagy genes. Oncogene 27: 4860-4864.

PUA HH, DZHAGALOV I, CHUCK M, MIZUSHIMA N AND HE YW. 2007. A critical role for the autophagy gene ATG5 in T cell survival and proliferation. J Exp Med 204: 25-31.

RISTIC B ET AL. 2014. Idarubicin induces mTOR-dependent cytotoxic autophagy in leukemic cells. Exp Cell Res 326: 90-102.

RUSSELL RC, TIAN Y, YUAN H, PARK HW, CHANG YY, KIM J, KIM H, NEUFELD TP, DILLIN A AND GUAN KL. 2013. ULK1 induces autophagy by phosphorylating Beclin-1 and activating VPS34 lipid kinase. Nat Cell Biol 15: 741-750.

SAGE J, MILLER AL, PEREZ-MANCERA PA, WYSOCKI JMAND JACKS T. 2003. Acute mutation of retinoblastoma gene function is sufficient for cell cycle re-entry. Nature 424: 223-228.

SAGE J, MULLIGAN GJ, ATTARDI LD, MILLER A, CHEN $\mathrm{S}$, WILLIAMS B, THEODOROU E AND JACKS T. 2000. Targeted disruption of the three Rb-related genes leads to loss of $\mathrm{G}(1)$ control and immortalization. Genes Dev 14: 3037-3050.

SARASTE A AND PULKKI K. 2000. Morphologic and biochemical hallmarks of apoptosis. Cardiovascular Research 45: 528-537.

SASAKI K ET AL. 2012. Resistance of colon cancer to 5-fluorouracil may be overcome by combination with chloroquine, an in vivo study. Anticancer Drugs 23: 675682.

SHAID S, BRANDTS CH, SERVE H AND DIKIC I. 2013. Ubiquitination and selective autophagy. Cell Death Differ 20: $21-30$. 
SHANGARY S ET AL. 2008. Temporal activation of $\mathrm{p} 53$ by a specific MDM2 inhibitor is selectively toxic to tumors and leads to complete tumor growth inhibition. Proc Natl Acad Sci USA 105: 3933-3938.

SHANGARY S AND WANG S. 2009. Small-molecule inhibitors of the MDM2-p53 protein-protein interaction to reactivate p53 function: a novel approach for cancer therapy. Annu Rev Pharmacol Toxicol 49: 223-241.

SHEN XG, WANG C, LI Y, WANG L, ZHOU B, XU B, JIANG X, ZHOU ZG AND SUN XF. 2010. Downregulation of caspase- 9 is a frequent event in patients with stage II colorectal cancer and correlates with poor clinical outcome. Colorectal Dis 12: 1213-1218.

SHI YH ET AL. 2011. Targeting autophagy enhances sorafenib lethality for hepatocellular carcinoma via ER stress-related apoptosis. Autophagy 7: 1159-1172.

SHIMIZU S, KANASEKI T, MIZUSHIMA N, MIZUTA T, ARAKAWA-KOBAYASHI S, THOMPSON CB AND TSUJIMOTO Y. 2004. Role of Bcl-2 family proteins in a non-apoptotic programmed cell death dependent on autophagy genes. Nat Cell Biol 6: 1221-1228.

SHINGU T, FUJIWARA K, BOGLER O, AKIYAMA Y, MORITAKE K, SHINOJIMA N, TAMADA Y, YOKOYAMA T AND KONDO S. 2009. Inhibition of autophagy at a late stage enhances imatinib-induced cytotoxicity in human malignant glioma cells. Int J Cancer 124: 1060-1071.

SIMPSON MT ET AL. 2001. Caspase 3 deficiency rescues peripheral nervous system defect in retinoblastoma nullizygous mice. J Neurosci 21: 7089-7098.

SIROIS I, GROLEAU J, PALLET N, BRASSARD N, HAMELIN K, LONDONO I, PSHEZHETSKY AV, BENDAYAN M AND HEBERT MJ. 2012. Caspase activation regulates the extracellular export of autophagic vacuoles. Autophagy 8: 927-937.

SUI X ET AL. 2013. Autophagy and chemotherapy resistance: a promising therapeutic target for cancer treatment. Cell Death Dis 4: e838.

SUN WL, CHEN J, WANG YP AND ZHENG H. 2011. Autophagy protects breast cancer cells from epirubicininduced apoptosis and facilitates epirubicin-resistance development. Autophagy 7: 1035-1044.

SWAMPILLAI AL, SALOMONI P AND SHORT SC. 2012. The role of autophagy in clinical practice. Clin Oncol (R Coll Radiol) 24: 387-395.

TALLURI S AND DICK FA. 2012. Regulation of transcription and chromatin structure by $\mathrm{pRB}$ : here, there and everywhere. Cell Cycle 11: 3189-3198.

TAN S, PENG X, PENG W, ZHAO Y AND WEI Y. 2015. Enhancement of oxaliplatin-induced cell apoptosis and tumor suppression by 3 -methyladenine in colon cancer. Oncol Lett 9: 2056-2062.

TASSA A, ROUX MP, ATTAIX D AND BECHET DM. 2003. Class III phosphoinositide 3-kinase--Beclin1 complex mediates the amino acid-dependent regulation of autophagy in C2C12 myotubes. Biochem J 376: 577-586.

TETER SA, EGGERTON KP, SCOTT SV, KIM J, FISCHER AM AND KLIONSKY DJ. 2001. Degradation of lipid vesicles in the yeast vacuole requires function of Cvt17, a putative lipase. J Biol Chem 276: 2083-2087.

THOMAS DM, CARTY SA, PISCOPO DM, LEE JS, WANG WF, FORRESTER WC AND HINDS PW. 2001. The retinoblastoma protein acts as a transcriptional coactivator required for osteogenic differentiation. Mol Cell 8: 303316.

THORNBERRY NA AND LAZEBNIK Y. 1998. Caspases: Enemies Within. Science 281: 1312-1316.

TOOZE SA AND YOSHIMORI T. 2010. The origin of the autophagosomal membrane. Nat Cell Biol 12: 831-835.

VELDHOEN RA, BANMAN SL, HEMMERLING DR, ODSEN R, SIMMEN T, SIMMONDS AJ, UNDERHILL DA AND GOPING IS. 2013. The chemotherapeutic agent paclitaxel inhibits autophagy through two distinct mechanisms that regulate apoptosis. Oncogene 32: 736746.

VILLENEUVE NF, LAU A AND ZHANG DD. 2010. Regulation of the Nrf2-Keap1 antioxidant response by the ubiquitin proteasome system: an insight into cullin-ring ubiquitin ligases. Antioxid Redox Signal 13: 1699-1712.

VOGLER M. 2014. Targeting BCL2-Proteins for the Treatment of Solid Tumours. Adv Med 2014: 943648.

WANG Y, PENG RQ, LI DD, DING Y, WU XQ, ZENG YX, ZHU XF AND ZHANG XS. 2011. Chloroquine enhances the cytotoxicity of topotecan by inhibiting autophagy in lung cancer cells. Chin J Cancer 30: 690-700.

WEINBERG RA. 1995. The retinoblastoma protein and cell cycle control. Cell 81: 323-330.

WHITE E AND DIPAOLA RS. 2009. The double-edged sword of autophagy modulation in cancer. Clin Cancer Res 15: 5308-5316.

XIONG HY ET AL. 2010. Autophagic cell death induced by 5-FU in Bax or PUMA deficient human colon cancer cell. Cancer Lett 288: 68-74.

XU Y, KIM SO, LI Y AND HAN J. 2006. Autophagy contributes to caspase-independent macrophage cell death. J Biol Chem 281: 19179-19187.

YANAGISAWA H, MIYASHITA T, NAKANO Y AND YAMAMOTO D. 2003. HSpin1, a transmembrane protein interacting with $\mathrm{Bcl}-2 / \mathrm{Bcl}-\mathrm{xL}$, induces a caspaseindependent autophagic cell death. Cell Death Differ 10: 798-807.

YAZDANKHAH M, FARIOLI-VECCHIOLI S, TONCHEV AB, STOYKOVA A AND CECCONI F. 2014. The autophagy regulators Ambral and Beclin 1 are required for adult neurogenesis in the brain subventricular zone. Cell Death Dis 5: e1403.

YOO SH, YOON YG, LEE JS, SONG YS, OH JS, PARK BS, KWON TK, PARK C, CHOI YH AND YOO YH. 2012. 
Etoposide induces a mixed type of programmed cell death and overcomes the resistance conferred by Bcl-2 in Hep3B hepatoma cells. Int J Oncol 41: 1443-1454.

YORIMITSU T AND KLIONSKY DJ. 2005. Autophagy: molecular machinery for self-eating. Cell Death Differ 12 (Suppl 2): 1542-1552.

YOUNG AR ET AL. 2009. Autophagy mediates the mitotic senescence transition. Genes Dev 23: 798-803.

YUE Z, JIN S, YANG C, LEVINE AJ AND HEINTZ N. 2003. Beclin 1, an autophagy gene essential for early embryonic development, is a haploinsufficient tumor suppressor. Proc Natl Acad Sci USA 100: 15077-15082.

ZENG X AND KINSELLA TJ. 2008. Mammalian target of rapamycin and S6 kinase 1 positively regulate 6-thioguanine-induced autophagy. Cancer Res 68: 23842390.

ZENG X, YAN T, SCHUPP JE, SEO Y AND KINSELLA TJ. 2007. DNA mismatch repair initiates 6-thioguanine-induced autophagy through p53 activation in human tumor cells. Clin Cancer Res 13: 1315-1321.

ZHANG SF ET AL. 2015. TXNDC17 promotes paclitaxel resistance via inducing autophagy in ovarian cancer. Autophagy 11: 225-238.

\section{SUPPLEMENTARY MATERIAL}

TABLE I - Autophagy is usually activated as a survival mechanism in response to therapeutic agents. 